\title{
Stream Acidification in the Catskill Mountains of New York
}

BY PETER S. MURDOCH and CHARLES R. BARNES

U.S. GEOLOGICAL SURVEY

Open-File Report 96-221 


\title{
U.S. DEPARTMENT OF THE INTERIOR \\ BRUCE BABBITT, Secretary
}

\author{
U.S. GEOLOGICAL SURVEY \\ Gordon P. Eaton, Director
}

For additional information write to:

District Chief, Water Resources Division

U.S. Geological Survey

425 Jordan Road

Troy, NY 12180
Copies of the report can be purchased from:

U.S. Geological Survey

Branch of Information Services

Box 25286

Denver, CO 80225 


\section{CONTENTS}

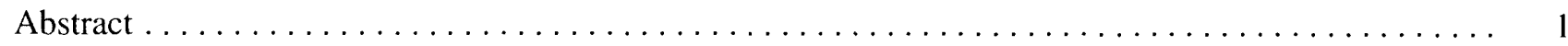

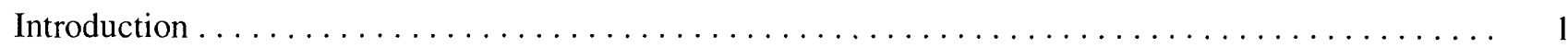

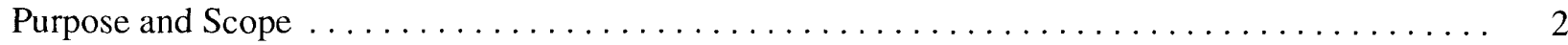

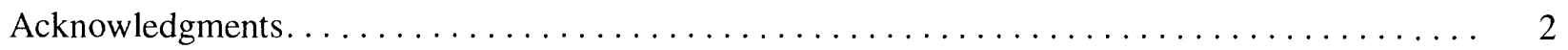

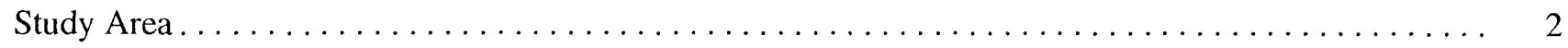

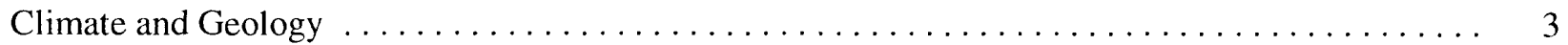

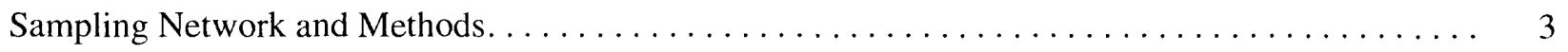

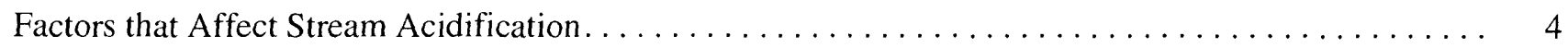

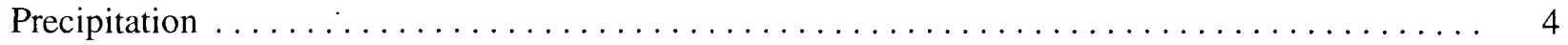

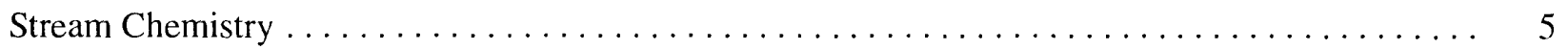

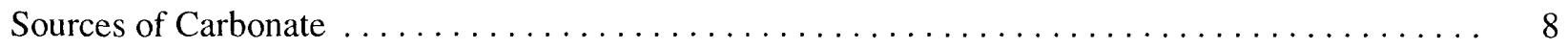

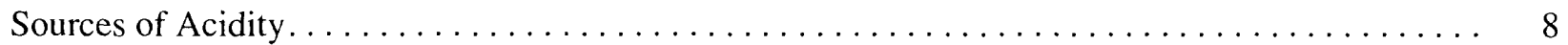

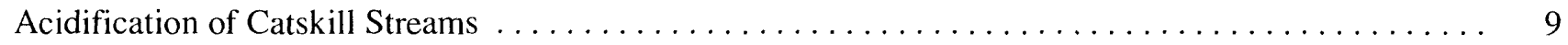

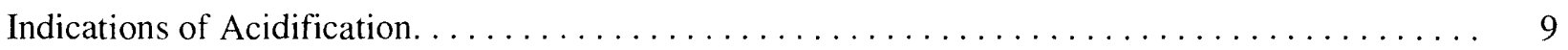

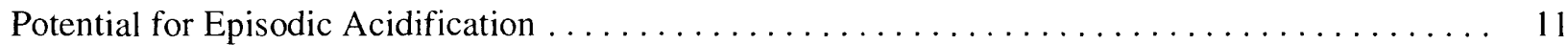

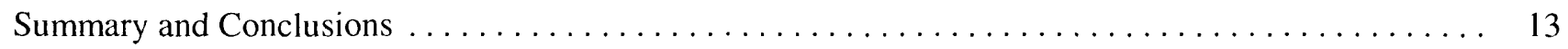

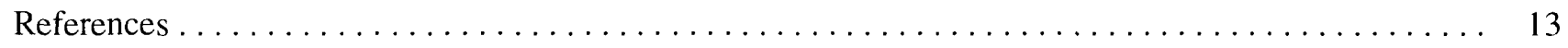

\section{FIGURES}

1. Map showing the location of Biscuit Brook, seven Long-Term Monitoring (LTM) streams, and

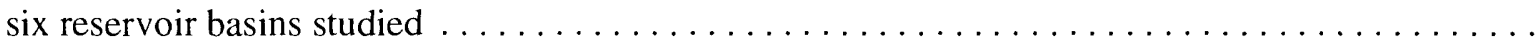

2. Plots of (A) sulfate and (B) base-cation concentration in samples from Biscuit Brook and the Long-Term Monitoring streams in relation to stream discharge, $1984-86 \ldots \ldots \ldots \ldots \ldots \ldots$

3. Plots of (A) alkalinity and (B) alkalinity plus sulfate in relation to $\mathrm{Ca}+\mathrm{Mg}$ concentrations in the Long-Term Monitoring streams, 1984-86

4. Plot of concentration of protolytic cations in relation to the ratio of acidic anions to base-cation concentration in the 66 regional-survey streams, 1984-86.

5. Plot of $\mathrm{pH}$ and alkalinity in relation to discharge at Biscuit Brook and the Long-Term Monitoring streams, 1984-86.

6. Plot of $\mathrm{pH}$ in relation to aluminum concentration at Biscuit Brook and Long-Term Monitoring streams, 1984-86.

7. Flow-duration curves for the Neversink River near Claryville (1953-85) and at Biscuit Brook (1984-85).

\section{TABLES}

1. Average volume-weighted annual concentrations of dissolved constituents and $\mathrm{pH}$ in weekly precipitation samples from Biscuit Brook, N. Y. and other monitoring stations in the northeastern United States.

2. Average-annual concentrations of dissolved constituents in Catskill Mountain stream water, 1983-86: A. Biscuit Brook and the Long-Term Monitoring streams, B. Regional Survey streams. . . 


\section{CONVERSION FACTORS}

\begin{tabular}{rll}
\hline Multiply & By & To obtain \\
\hline centimeter $(\mathrm{cm})$ & 0.3937 & inch (in.) \\
$\operatorname{meter}(\mathrm{m})$ & 3.281 & foot $(\mathrm{ft})$ \\
kilometer $(\mathrm{km})$ & 0.621 & mile $(\mathrm{mi})$ \\
square kilometer $\left(\mathrm{km}^{2}\right)$ & 0.3861 & square mile $\left(\mathrm{mi}^{2}\right)$ \\
$\operatorname{liter}(\mathrm{L})$ & 0.2642 & gallon (gal) \\
milliliter $(\mathrm{mL})$ & 0.338 & fluid ounce $(\mathrm{oz})$ \\
cubic meter per second $\left(\mathrm{m}^{3} / \mathrm{s}\right)$ & 35.31 & cubic foot per second $\left(\mathrm{ft}^{3} / \mathrm{s}\right)$ \\
degree Celsius $\left({ }^{\circ} \mathrm{C}\right)$ & $\left(1.8 \mathrm{x}{ }^{\circ} \mathrm{C}\right)+32$ & degree Fahrenheit $\left({ }^{\circ} \mathrm{F}\right)$ \\
gram $(\mathrm{g})$ & 28.35 & ounce (oz) \\
cubic feet per second per square $\mathrm{kilometer}$ & 13.633 & $\begin{array}{l}\text { cubic foot per second per } \\
\text { square mile }\end{array}$ \\
\hline$\left.\left[\mathrm{m}^{3} / \mathrm{s}\right] / \mathrm{km}\right)^{2}$ & &
\end{tabular}

\section{Other Abbreviations}

microsiemens per centimeter at $25^{\circ} \mathrm{C}(\mu \mathrm{S} / \mathrm{cm})$

microequivalents per liter $(\mu \mathrm{eq} / \mathrm{L})$

milliequivalents per liter $(\mu \mathrm{eq} / \mathrm{L})$

milligrams per liter $(\mathrm{mg} / \mathrm{L})$

micrometer $(\mu)$

milliequivalents per milligram (meq/mg)

year $(\mathrm{yr})$

greater than $(>)$

less than $(<)$

\section{Water Year}

The 365-day period from October 1 through

September 30 of the following year.

Sea level:In this report "sea level" refers to the National Geodetic Vertical Datum of 1929 (NGVD of 1929) - a geodetic datum derived from a general adjustment of the first-order level nets of both the United States and Canada, formerly called Sea Level Datum of 1929. 


\title{
Stream Acidification in the Catskill Mountains of New York
}

\author{
By Peter S. Murdoch and Charles R. Barnes
}

\section{Abstract}

Results of stream and precipitation monitoring in the Catskill Mountains of New York during 1983-86 indicate acidification of some streams by sulfuric and nitric acid in atmospheric deposition. Concentrations of major ions in precipitation were similar to those reported at other sites in the Northeast. Average concentrations of sulfate and nitrate were similar among the streams, but base-cation concentrations differed widely and paralleled differences in stream alkalinity. Relations between sulfate concentrations and discharge were similar among streams for discharges ranging over three orders of magnitude. Measured differences between concentrations of alkalinity and concentrations of calcium and magnesium were equivalent to concentrations of sulfate. Episodic decreases in alkalinity and $\mathrm{pH}$ during peak flows were associated with increases in nitrate concentrations during all seasons except midsummer.

Concentrations of hydrogen and dissolved aluminum in streams increased when concentrations of sulfate plus nitrate exceeded 80 percent of the sum of base-cation concentrations. During snowmelt in 1986, dissolved aluminum concentrations in 30 percent of the streams exceeded 50 milligrams per liter. At base flow, alkalinity concentrations exceeded $200 \mu \mathrm{eq} / \mathrm{L}$ (microequivalents per liter) in about 48 percent of the streams, ranged from 0 to 200 $\mu \mathrm{eq} / \mathrm{L}$ in about 45 percent of the streams, and were not measurable (streams were acidified) in 7 percent of the streams.

\section{INTRODUCTION}

The effects of acidic deposition on lake and stream chemistry in the northeastern United States have been extensively analyzed (Driscoll and Newton, 1986; Hemond and Eshleman, 1984). Most research has focused on the effects in specific watersheds and on mechanisms that control the acidification process (Peters and Murdoch, 1985; Hemond and Eshleman, 1984; Likens and others, 1977). Recently, however, surveys of surface waters across large regions have been conducted to address the extent of the effects documented in the site-specific research programs (Haines and Akielaszek, 1983; Arnold and others, 1985; Lynch and Dise, 1985; Linthurst and others, 1986). For example, streamwater quality in 56 basins in Shenandoah National Park, Va., has been shown to be significantly correlated with bedrock type (Lynch and Dise, 1985), and the relative uniformity of stream chemistry among basins with similar bedrock allowed prediction of the sensitivity of nearby unmonitored streams to acidic deposition.

The streams of the Catskill Mountains in southeastern New York (fig. 1) are noted for trout fishing and also feed six reservoirs of the New York City water-supply system. Data on stream chemistry, gathered during the fall of 1982 by the U.S. Geological Survey (USGS) indicate that several Catskill streams are poorly buffered and, thus, sensitive to acidic deposition. The Catskill Mountains area has a relatively uniform bedrock composition; therefore, bedrock type alone cannot account for observed differences in water quality among the streams.

As a result of the 1982 stream-sampling program, the USGS, in cooperation with the U.S. Environmental Protection Agency and the New York City Department of Environmental Protection, established a three-part stream-monitoring network in 1983 that included weekly to hourly sampling at one stream (Biscuit Brook), approximately monthly sampling at seven other streams (the Long-Term Monitoring or "LTM" streams), and seasonal sampling at 58 other headwater streams in the six reservoir watersheds (the Regional Survey streams). This network allowed comparison of data from the many sites to evaluate whether or not the the LTM streams and Biscuit Brook are representative of stream conditions in the Catskill region as a whole. This, in turn, allowed an assessment of the status of stream acidification in the Catskill Mountains of New York. 


\section{Purpose and Scope}

This report describes the study area and methods used for the USGS Catskill stream-monitoring program and describes the status of stream acidity and concentration-to-discharge relations in streams of the Catskill Mountain region during the first 4 years of monitoring. Data used in this report were collected from April 1983 through May 1986.

\section{Acknowledgments}

Funding for Catskill stream and precipitation research is being provided by the U.S. Geological Survey and the U.S. Environmental Protection Agency as part of the National Acid Precipitation Assessment Program (NAPAP), and by the New York
City Department of Environmental Protection. The Frost Valley YMCA provided observer services. Special thanks are extended to the property owners who allowed access to streams.

\section{STUDY AREA}

The Catskill Mountain region encompasses parts of Ulster, Sullivan, Delaware, and Greene counties in southeastern New York (fig. 1). The mountains are erosional remnants of a large delta that was deposited from the east into a shallow inland sea that is now western New York. The mountains form the northernmost extension of the Appalachian Plateau and give way to gently rolling hills to the south and west; they terminate abruptly to the east at the edge of the Hudson River Valley (fig. 1).

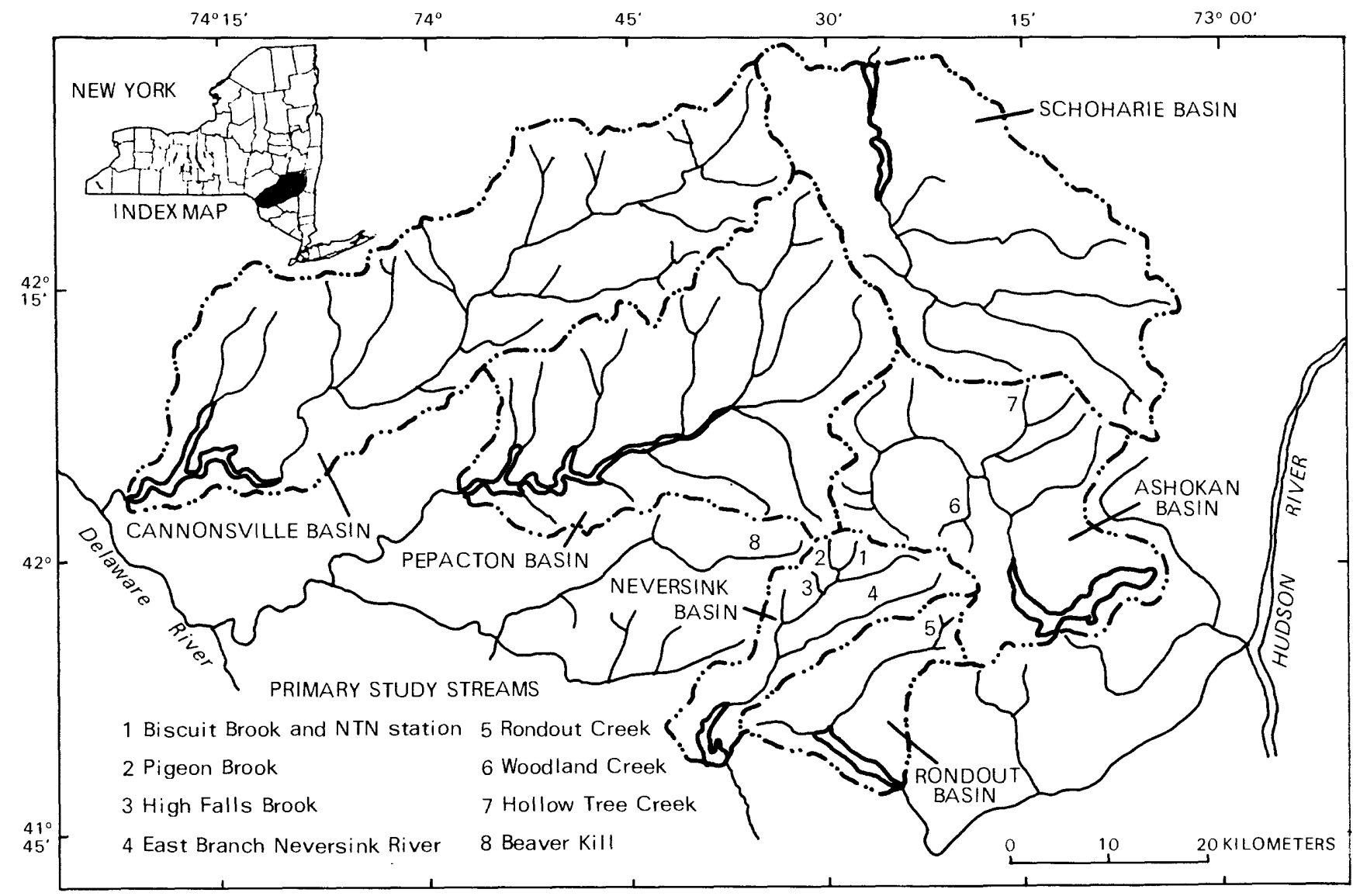

Figure 1. Location of Biscuit Brook, the seven Long-Term Monitoring (LTM) streams, and the six reservoir basins studied. (Modified from Murdoch, 1991, fig. 7.) 


\section{Climate and Geology}

The Catskill region typically has moderately cool summers and cold winters. Average annual air temperature is $5^{\circ} \mathrm{C}$. Annual precipitation from the National Weather Service's Slide Mountain station in the headwaters of the West Branch Neversink River (fig. 1) averaged $157 \mathrm{~cm}$, of which about 18 percent $(28 \mathrm{~cm} / \mathrm{yr}$ ) was snow (National Oceanic and Atmospheric Administration, 1974-85). The region receives precipitation from coastal storms, frontal systems from the west, and local thunderstorms. Heavy dew is common during the summer.

All streams in the region are underlain by bedrock of Devonian age that consists of flat-lying, interbedded sandstones, shales, and conglomerates that were deposited in a massive westward flowing delta (Rich, 1934). The bedrock is a moderate to poor aquifer and is relatively unreactive chemically (Parker and others, 1964). The detrital fraction of these sedimentary rocks consists primarily of quartz grains (78 percent ) and fragments of metamorphic rocks (16 percent ) (Ethridge, 1977).

Till derived from both continental and alpine glaciation overlies all stream basins, but its thickness varies. Maps of glacial striations on bedrock ridges (Rich, 1934) suggest that ice movement was southward or southwestward in all basins except the Ashokan, where movement was west to northwestward (fig. 1). In general, about 97 percent of the till consists of local rock material; the remainder consists of exotic rock fragments from the north and east (Rich, 1934). The Catskill highlands are flanked on the north and northeast by limestone escarpments that were scoured and plucked by the southward moving ice. Local variations in the amount of carbonate rock fragments within till has been suggested as the primary difference in till composition among the basins (R. J. Dineen, New York State Geological Survey, oral commun., 1985).

Lake-clay deposits overlie the till in much of the Schoharie Creek valley (fig. 1). The Schoharie basin also has less outwash and moraine from the continental glaciers than the Ashokan and Cannonsville basins and more moraine deposits from local alpine glaciation (Rich, 1934). The Neversink and Roundout basins to the south contain only a few morainal deposits and have narrow, steep-sided valleys that show signs of meltwater scouring.

Catskill soils are primarily Inceptisols, and have a low sulfate-adsorption capacity and moderate to high acidity. Drainage-divide elevations are higher and basin slopes are generally greater in the southern and eastern parts of the region than elsewhere. Results of recent soil surveys of the Ashokan and Schoharie basins suggest a mean soil $\mathrm{pH}$ of 4.4 (based on an average of hydrogen-ion concentration) and a moderate to low mean cation-exchange capacity of $5.67 \mathrm{meq} / 100 \mathrm{~g}$ (Ceraso and others, 1986).

\section{Sampling Network and Methods}

The most comprehensive sampling station in the Catskill network was established at Biscuit Brook near Frost Valley, N.Y. in April 1983 (fig. 1). Data collection there includes continuous flow monitoring, weekly water-quality sampling, and at least hourly water sampling during selected highflow periods. A precipitation-monitoring station for collection of precipitation volume and weekly wetfall-chemistry data was established in the Biscuit Brook watershed in September 1983 as part of the USGS National Trends Network (NTN).

Seven other streams representing a range of baseflow alkalinity values, were measured for discharge and water quality 9 to 12 times yearly beginning in August 1983 as part of the Long-Term Monitoring (LTM) network. These streams and Biscuit Brook are referred to herein as the "primary streams" of the network. Beginning in June 1985, an additional 58 headwater streams, all within the six basins that feed New York City reservoirs, were monitored four to six times per year for water quality and stream stage. The entire group of 66 streams is referred to herein as the "regional survey" network.

The six stream basins in the regional survey network represent a variety of orientations, elevations, and land use. Streams in the northern four basins (Schoharie, Ashokan, Pepacton, and Cannonsville; fig. 1) have greater population density and agricultural activity than those in the two southern basins (Neversink and Rondout). Except for the main feeder stream to each reservoir, all stations in the network are on streams that drain small headwater basins.

All 66 streams were sampled for major ions and dissolved aluminum concentrations in accordance with the sampling protocol of the National Acid Precipitation Assessment Program (NAPAP) (Charles Powers, U.S. Environmental Protection Agency, written commun., 1984) and USGS methods for lowionic-strength waters (Murdoch, 1991). In addition, 
Biscuit Brook and the LTM streams were monitored for discharge and sampled for dissolved organic carbon. Biscuit Brook was sampled weekly, and discharge was monitored continuously. Stream-water samples were collected manually in Teflon ${ }^{1}$ bottles, immediately chilled, and filtered within 24 hours. Samples were analyzed for $\mathrm{pH}$, alkalinity (by incremental titration), and specific conductance before being sent to the USGS National Water Quality Laboratory in Denver, Colo. for analysis. Samples were analyzed for sulfate, nitrate, and chloride concentrations by ion chromatography, and for base cation (calcium, magnesium, sodium, and potassium) concentrations by inductively coupled plasma techniques. Dissolved aluminum aliquots were filtered through $0.1-\mu \mathrm{m}$ filters; aluminum concentra- . tions were determined by direct-coupled plasma, and dissolved organic carbon concentrations by wet oxidation and infrared spectrometry (Fishman and Friedman, 1985). Samples collected after September 1985 were analyzed for major anion concentrations on an ion chromatograph at the USGS field laboratory in Albany, N.Y. Weekly precipitation samples were analyzed for $\mathrm{pH}$ and specific conductance in the field and shipped to the Illinois State Water Survey Laboratory in Champaign, Ill., for major-ion analysis.

A quality-control program including blind audit, duplicate, split, and blank samples was conducted throughout the study. Analyses were checked for both charge balance and agreement between measured and calculated specific conductance; samples differing by more than 10 percent were reanalyzed. A complete description of qualitycontrol procedures and results is presented in Murdoch (1991). Calculations of annual stream yield at Biscuit Brook were made by applying the Johnson model (Johnson and others, 1969).

\section{FACTORS THAT AFFECT STREAM ACIDIFICATION}

Several environmental factors within the watershed of each stream can influence both the acidity of stream water and the capacity of the watershed to resist surface-water acidification.

I Use of trade, product, or firm names in this publication is for descriptive purposes only and does not imly endorsement by the U.S. Government.
Incoming acidity from atmospheric deposition must be neutralized within a watershed to avoid stream acidification; differences in deposition rates among watersheds could therefore cause differences in stream acidity if all other factors are comparable. The buffering capacity of soils within each watershed could differ as a result of differences in soil chemistry, permeability, thickness, etc.

Although data for determining the processes that control stream acidity in the LTM streams were not collected for this analysis, data on precipitation acidity, stream concentration-to-discharge relations, and comparisons of these indicators with surface waters in other parts of the Northeast where process research has been done can indicate the primary factors that cause differences in acidity among the study streams.

\section{Precipitation}

Average concentrations of major constituents of precipitation samples collected at Biscuit Brook were similar to those at other monitoring stations in the Northeast, but precipitation volumes were greater (table 1) (Murdoch, 1991). Precipitation amounts at the National Weather Service station in the Neversink basin averaged $149 \mathrm{~cm} / \mathrm{yr}$ during the study, 5 percent below the 10-year average of 157 $\mathrm{cm} / \mathrm{yr}$. Precipitation amounts at stations just west and south of the Catskill Mountains averaged 32 percent and 46 percent less over 10 years (1975-84), respectively, than the National Weather Service's Slide Mountain station near Biscuit Brook (Murdoch, 1991). Average volume-weighted hydrogen-ion concentration in precipitation was equivalent to a $\mathrm{pH}$ of 4.26 for the 2-year period of record, and weekly $\mathrm{pH}$ values ranged from 3.25 to 5.92 (Murdoch, 1991). Hydrogen ion accounted for 66 percent of the cation load, and ammonium (the next most abundant ion) accounted for 16 percent. Of the anion load, sulfate accounted for 58 percent, and nitrate for 34 percent (table 1).

Precipitation volume varied across the Catskill region; the greatest annual volumes were in the Neversink, Rondout, and Ashokan watersheds. Although precipitation chemistry was relatively uniform within the region, local variations in precipitation volume may have caused differences in chemical loadings (Stoddard and Murdoch, 1991). 
Table 1. Average annual precipitation-weighted annual concentrations of dissolved constituents, $\mathrm{pH}$, and volume of weekly precipitation samples from Biscuit Brook and other monitoring stations in the northeastern United States

[Values in microequivalents per liter unless otherwise noted; WY = water year (Oct. 1 through Sept. 30); cm, centimeters]

\begin{tabular}{|c|c|c|c|c|c|c|c|}
\hline \multirow{2}{*}{$\begin{array}{l}\text { Constituent or } \\
\text { characteristic }\end{array}$} & \multicolumn{2}{|c|}{ Biscuit Brook } & \multicolumn{2}{|c|}{ Leading Ridge, $\mathrm{Pa}^{\mathrm{a}}$} & \multirow{2}{*}{$\begin{array}{c}\begin{array}{c}\text { Hubbard } \\
\text { Brook, N.H. }\end{array} \\
1984\end{array}$} & \multicolumn{2}{|c|}{ Huntington, N.Y. } \\
\hline & WY 84 & WY 85 & 1984 & 1985 & & 1984 & 1985 \\
\hline $\mathrm{SBC}^{\mathrm{b}}$ & 16.6 & 13.9 & 15.0 & 11.5 & 10.6 & 10.5 & 9.6 \\
\hline $\mathrm{NH}^{+}$ & 14.3 & 12.7 & 17.8 & 13.3 & 9.4 & 10.0 & 10.0 \\
\hline $\mathrm{H}$ & 56.8 & 53.3 & 70.7 & 60.2 & 38.8 & 37.5 & 42.3 \\
\hline $\mathrm{SO}_{4}$ & 40.1 & 47.1 & 69.2 & 56.4 & 34.5 & 36.8 & 39.7 \\
\hline $\mathrm{NO}_{3}$ & 23.9 & 26.3 & 35.9 & 28.5 & 20.6 & 20.1 & 23.8 \\
\hline $\mathrm{Cl}^{-}$ & 6.3 & 5.5 & 5.3 & 5.1 & 4.5 & 3.1 & 2.8 \\
\hline $\mathrm{pH}$ (units) & 4.24 & 4.27 & 4.15 & 4.22 & 4.41 & 4.43 & 4.37 \\
\hline Volume $(\mathrm{cm})$ & 168 & 130 & 113 & 107 & 125 & 109 & 102 \\
\hline
\end{tabular}

a NADP/NTN Coordinator's Office (1986, 1987)

b $\mathrm{SBC}=$ Sum of base cations $(\mathrm{Ca}+\mathrm{Mg}+\mathrm{Na}+\mathrm{K})$

\section{Stream Chemistry}

Analyses of mean discharge-weighted concentrations of major chemical constituents of streams studied (the East Branch and West Branch of the Neversink basin are treated separately in the regional survey data) indicate three major characteristics:

1) Concentrations of calcium and, to a lesser extent, magnesium, differed markedly among the streams.

2) Alkalinity and $\mathrm{pH}$ differed markedly among the streams and generally followed the pattern of calcium concentrations.

3) Concentrations of sulfate and nitrate were relatively uniform among the streams (table 2).

The highest concentrations of all constituents except hydrogen ion and aluminum were in the westernmost basin (Cannonsville); calcium and magnesium concentrations there were twice as high as those in the two southernmost basins (Neversink and Rondout), but sulfate concentrations in the Cannonsville basin were only 12 percent higher. Sodium concentrations were similar among the eight primary streams but highly variable among the regional-survey basins, probably as a result of highway deicing. An analysis of variance of the LTM stream data and the regional-survey data indicate that the minor differences in sulfate concentrations among the streams are not statistically significant. A similar statistical analysis of calcium, magnesium, and alkalinity concentrations indicate statistically significant $(\alpha>$ 0.05 ) differences among Biscuit Brook, the LTM streams, and the regional survey streams.

The relation between sulfate concentrations and stream discharge per unit area also was relatively uniform among the LTM streams (fig. 2A); all LTM streams had similar sulfate concentrations at flows ranging through three orders of magnitude. Sulfate concentrations were slightly elevated in the streams with high alkalinity and were lowest in the most acidic stream (East Branch Neversink River) (table 2).

Base-cation concentrations differed widely from stream to stream at low discharges but became similar as discharge per unit area increased (fig. 2B). Streams with high base-cation concentrations at low discharges showed the largest decreases in basecation concentrations as discharges increased. The smallest decrease in base-cation concentrations with increased discharge was in the East Branch Neversink, the most acidic stream studied (total decrease of approximately $15 \mu \mathrm{eq} / \mathrm{L}$ ). The differences in cation concentrations among the streams suggest variability in the concentration of cations supplied by ground water at base flow, and the increased similarity in base-cation 
Table 2. Average annual concentrations of dissolved constituents in Catskill Mountain stream water, 1983-86.

[Locations are shown in fig. 1. Concentrations are in microequivalents per liter except aluminum, which is in micrograms per liter, and dissolved organic carbon (DOC), in milligrams per liter. Alk = Alkalinity. Values in part A are volume weighted; values in part $B$ are averages of the samples collected.]

\section{A. BISCUIT BROOK AND LONG-TERM MONITORING STREAMS}

\begin{tabular}{|c|c|c|c|c|c|c|c|c|c|c|c|c|}
\hline \multirow[b]{2}{*}{ Stream } & \multicolumn{11}{|c|}{ Constituents and characteristics } & \multirow{2}{*}{$\begin{array}{c}\text { Number } \\
\text { of } \\
\text { samples }\end{array}$} \\
\hline & $\mathrm{pH}^{\mathrm{a}}$ & $\mathrm{Ca}$ & Mg & $\mathrm{Na}$ & $\mathbf{K}$ & $\mathrm{NH}_{4}{ }^{\mathrm{b}}$ & $\mathrm{SO}_{4}$ & $\mathrm{NO}_{4}$ & $\mathrm{Cl}$ & Alk & DOC & \\
\hline Biscuit Brook & 5.4 & 101 & 35 & 16 & 8.0 & 0.01 & 119 & $21(92.8)$ & 11 & 11 & 3.7 & 193 \\
\hline Hollow Tree Brook & 6.9 & 276 & 75 & 26 & 6.8 & .00 & 149 & $47(59.3)$ & 21 & 136 & 2.7 & 17 \\
\hline High Falls Brook & 5.5 & 152 & 35 & 16 & 7.3 & .00 & 122 & $31(62.6)$ & 15 & 27 & 3.3 & 44 \\
\hline Beaverkill & 5.9 & 158 & 30 & 10 & 6.6 & .01 & 120 & $30(85.7)$ & 11 & 31 & 3.8 & 21 \\
\hline Pigeon Brook & 5.6 & 130 & 38 & 15 & 6.7 & .01 & 122 & $23(59.3)$ & 14 & 20 & 4.1 & 42 \\
\hline Woodland Creek & 6.1 & 95 & 53 & 15 & 6.9 & .01 & 114 & $22(40.5)$ & 14 & 14 & 2.6 & 12 \\
\hline Rondout Creek & 4.9 & 79 & 45 & 18 & 7.2 & .02 & 129 & $22(67.1)$ & 16 & -8 & 2.6 & 29 \\
\hline East Branch Neversink & 4.6 & 63 & 45 & 16 & 7.2 & .01 & 118 & $28(55.7)$ & 14 & -23 & 4.6 & 47 \\
\hline Catskill average & 5.2 & 131 & 44 & 16 & 7.1 & .01 & 124 & 28 & 14 & 26 & 3.4 & \\
\hline
\end{tabular}

\section{B. REGIONAL SURVEY STREAMS}

Constituents and characteristics

\begin{tabular}{|c|c|c|c|c|c|c|c|c|c|c|c|}
\hline \multirow[b]{2}{*}{ Drainage basin } & & \multirow[b]{2}{*}{$\begin{array}{c}\text { No. of } \\
\text { streams }\end{array}$} \\
\hline & $\mathrm{pH}^{\mathrm{a}}$ & $\mathrm{Ca}$ & $\mathrm{Mg}$ & $\mathrm{Na}$ & K & $\mathrm{SO}_{4}$ & $\mathrm{NO}_{3}{ }^{b}$ & $\mathrm{Cl}$ & Alk & Al & \\
\hline Ashokan & 6.7 & 208 & $\overline{78}$ & 46 & 7.1 & 137 & $27(61)$ & 35 & 127 & $\overline{19}$ & 7 \\
\hline Cannonsville & 7.0 & 297 & 118 & 86 & 24.5 & 158 & $36(96)$ & 63 & 235 & 16 & 8 \\
\hline East Branch Neversink & 4.9 & 77 & 49 & 16 & 7.5 & 123 & $28(66.5)$ & 15 & -17 & 219 & 9 \\
\hline West Branch Neversink & 5.8 & 139 & 47 & 24 & 7.5 & 127 & $31(70)$ & 26 & 28 & 161 & 9 \\
\hline Pepacton & 6.9 & 252 & 74 & 38 & 10.3 & 149 & $41(100)$ & 34 & 143 & 16 & 6 \\
\hline Rondout & 5.9 & 113 & 60 & 30 & 11.8 & 138 & $30(70)$ & 28 & 11 & 75 & 4 \\
\hline Schoharie & 6.6 & 193 & 65 & 53 & 8.0 & 144 & $28(63)$ & 36 & 94 & 28 & 6 \\
\hline
\end{tabular}

a pH value represents the mean hydrogen-ion concentration.

b Values in parentheses are observed peak values for period of record (1983-86)

concentrations during increasing discharge is probably due to the influx of shallow soil water and precipitation, which become large contributors during storms as the water tables rise and the flow paths of water become shallow in all watersheds. Comparison of the Catskill stream data with data from Hubbard Brook in New Hampshire and from lake-outlet streams in the Adirondack Mountains of northern New York shows the streams of all three regions to have similar sulfate and nitrate concentrations. Average sulfate concentrations in Hubbard Brook and Adirondack lake outlets were 123 and 136 $\mu$ eq/L, respectively (Likens, 1985; Driscoll and Newton, 1986), similar to $124 \mu \mathrm{eq} / \mathrm{L}$ in the Catskill LTM streams but slightly less than $143 \mu \mathrm{eq} / \mathrm{L}$ in the Catskill regional survey streams. The higher value for the regional-survey streams is due to the inclusion of the more highly developed Cannonsville and Pepacton basins and a slight bias toward lower discharges during sampling in these basins. Average nitrate concentrations in the Catskill streams were 28 $\mu \mathrm{eq} / \mathrm{L}$ in the LTM streams and $24 \mu \mathrm{eq} / \mathrm{L}$ in the regional-survey streams; these values are similar to the average of $30 \mu \mathrm{eq} / \mathrm{L}$ at Hubbard Brook, N.H. 

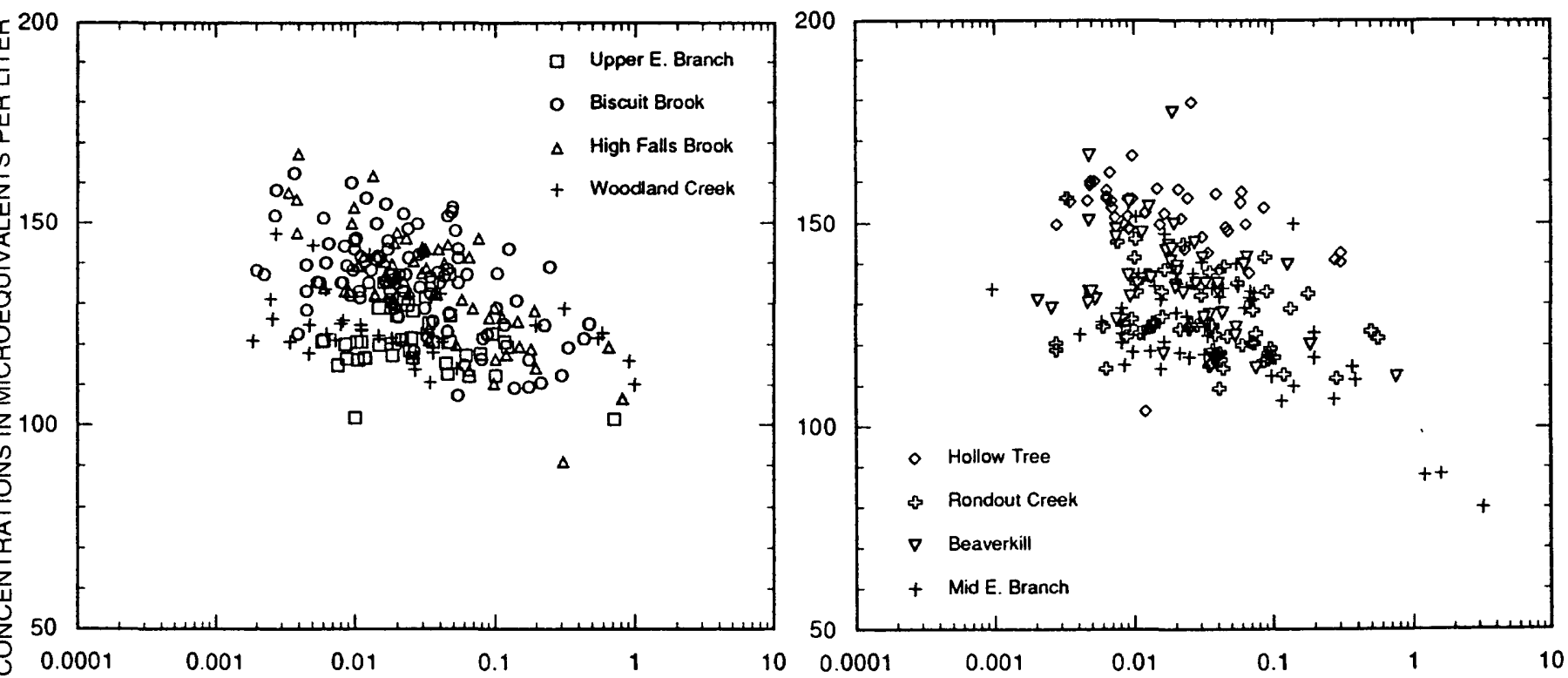

A. SULFATE DISCHARGE, IN CUBIC METERS PER SECOND PER SQUARE KILOMETER

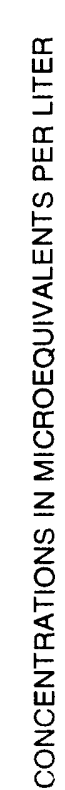
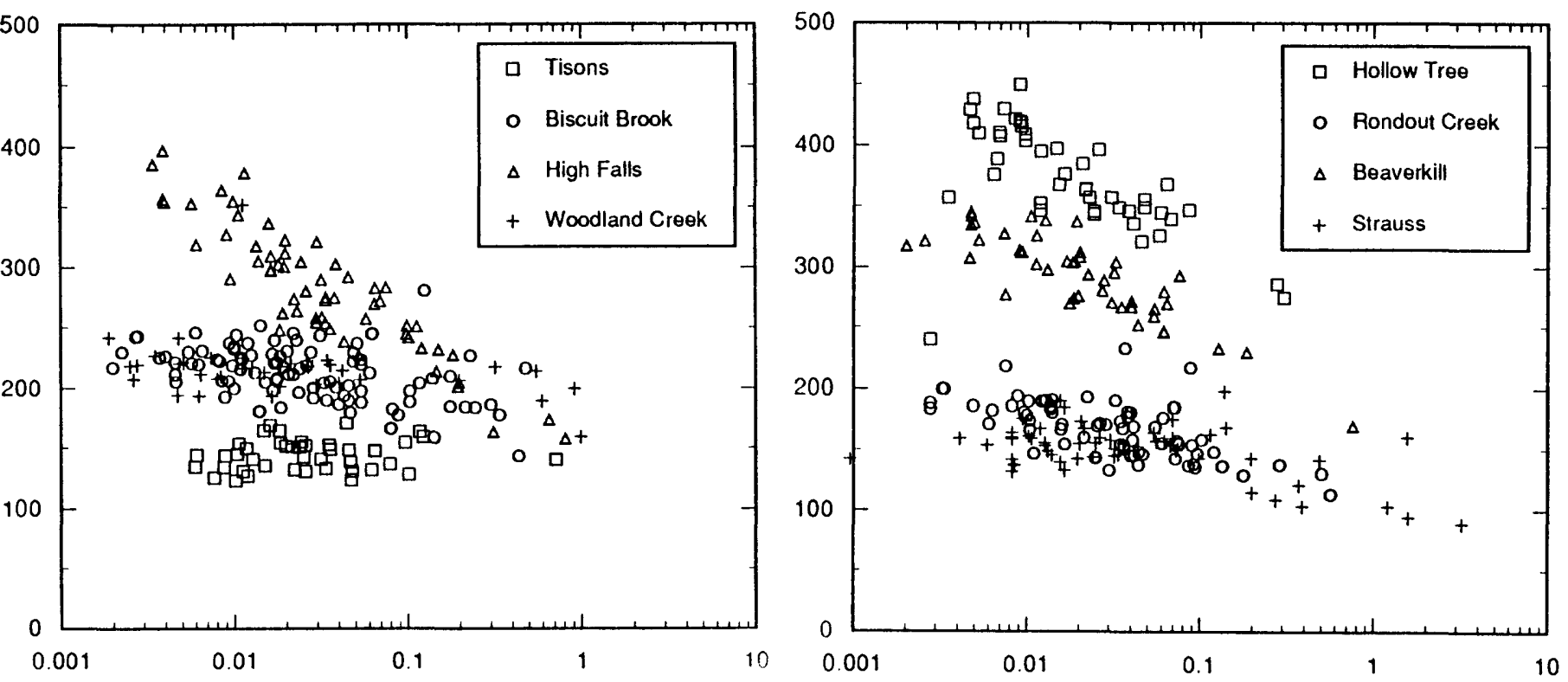

B. BASE CATIONS DISCHARGE, IN CUBIC METERS PER SECOND PER SQUARE KILOMETER

Figure 2. Sulfate and base-cation concentrations in samples from the Long-Term Monitoring streams in relation to stream discharge, 1984086. A. Sulfate. B. Base cations.

Average nitrate concentrations in the Adirondack lake outlets ranged from similar to Catskill values to considerably lower (between 29 and $4 \mu \mathrm{eq} / \mathrm{L}$ ), probably as a result of greater biological uptake of nitrate in lake than in stream environments (Driscoll and Newton, 1986). The relative similarity of major anion concentrations among these three locations suggests that the major cause of differences in stream-water $\mathrm{pH}$ and alkalinity at base flow is the availability of exchangeable and weatherable base cations, rather than differences in the amount of sulfuric and nitric acids present. 


\section{Sources of Carbonate}

The observed distribution of calcium and magnesium in the Catskill region is probably the result of several factors. Some of the calcium and magnesium in streams in the Cannonsville and Pepacton basins is derived from lime used in agriculture and possibly from calcium chloride used from highway deicing during the winter. Highway deicing is more prevalent in the four northern Catskill basins than in the Rondout and Neversink basins; dust from agricultural activity and unpaved roads may also contribute to the greater cation concentrations in streams of the four northern basins. (The valleys of the Neversink River and Rondout Creek in the southern Catskills have little or no agriculture and fewer road crossings upstream from sampling sites than the other basins.) The contributions from these sources do not account for the large differences in calcium and magnesium concentrations among the regional-survey streams, however.

The calcium and magnesium content of bedrock in the Catskill region may increase westward. Bedrock units in the Catskill area were deposited in a westwardly prograding delta on the edge of a shallow sea that covered much of what is now central New York (Ethridge, 1977). The distal (western) edge of that delta would therefore have been under marine conditions and would have incorporated salts and carbonates. Thus, bedrock in the westernmost (Cannonsville) basin would contain the greatest amount of carbonate, and the Pepacton basin the next greatest, as indicated by the relative calcium and alkalinity concentrations. This hypothesis does not explain differences in alkalinity among streams in the Neversink, Ashokan, and Schoharie basins, however.

Differences in the amount of carbonate in each basin could also be caused by the irregular distribution of limestone plucked by glacial ice during the last glaciation from surface exposures of limestone units north and east of the Catskill region. As ice moved southward across the Catskills, it would have deposited more debris from the limestone source on the leeward side of any high topographic features it encountered, creating a till "shadow." The limestone content of the till would have been greatest at the ridge closest to the limestone source and would have decreased over successive ridges (fig. 2). The Neversink and Rondout basins, which are farther from the limestone source, would therefore have received a smaller amount of carbonate than the northern basins. Recent studies of till stratigraphy in the western Catskills have revealed cobbles of Adirondack origin in the Cannonsville basin, but not in the Pepacton basin (D. Ozvath, Lafayette University, written commun., 1987). If materials from the Adirondack Mountains were transported to the Catskill region, limestone fragments from the intervening Helderberg Plateau would probably have been brought in also, and, like the Adirondack cobbles, would diminish southward. The presence of small amounts of carbonate in till has been documented as a controlling factor of stream alkalinity in several other areas (Drever and Hurcomb, 1986, Katz and others, 1985).

The thickness and distribution of permeable surficial material affects the residence time of water in a basin and, in turn, the base-cation concentrations in stream water. The till-source hypothesis would indicate that the northernmost basin (Schoharie) should have received the greatest percentage of carbonate, yet its streams have the lowest calcium concentrations of the northern basins. This may be because the Schoharie valley received deposition of lake clay over the till, which could have reduced the subsequent availability of carbonates for weathering. Because the thickness and permeability of surficial deposits can differ widely among the basins, these factors could have a greater effect on the streams' buffering capacity than could differences in carbonate content alone. Although a detailed analysis of these characteristics of local glacial deposits was beyond the scope of this study, the stream-chemistry data suggest that the surficial materials are an important factor in the chemical differences among Catskill streams.

\section{Sources of Acidity}

Several explanations for the presence of strong acids in streams and lakes of low ionic strength have been presented in the literature since the late 1970's. The major source of strong acids has been identified as atmospheric deposition of sulfuric acid, nitric acid, and sulfur and nitrous oxide compounds (National Research Council, 1983). Also, the role of several other acidification processes has come under discussion, including the oxidation of sulfides and nitrogen compounds, the decay of organic materials, and the redevelopment of biological systems after destructive land use in the watersheds (Rosenquist, 1978; Krug and Frink, 1983; Driscoll and Newton, 1986). 
Weathering of sulfur-bearing minerals in the Catskill region was considered as a possible source of stream sulfate in this study. Pyrite has been observed in bedrock outcrops several kilometers to the east and south of the study area (Way, 1972). Sulfide distribution within a geologic facies is generally irregular, however, depending on the distribution of organic materials at the time of deposition. In contrast, sulfate concentrations in streams throughout the Catskill region are relatively uniform, as are those in atmospheric deposition (table 2). Sulfate loads in wet deposition and also the sulfate output-to-input ratios at Biscuit Brook were comparable to those in other areas of the northeastern United States in which sulfur-bearing minerals have been discounted as a significant source of sulfate in streams (Murdoch, 1991; Hemond and Eshleman, 1984). Therefore, atmospheric sulfate, not sulfate minerals, is probably the major source of sulfate in Catskill streams.

A release of nitrate from watersheds was shown to have accompanied stream acidification during snowmelt in the Adirondack Mountains and at Hubbard Brook, N.H. (Peters and Driscoll, 1987; Likens and others, 1977), whereas little or no release of nitrate throughout the year has been observed at Bickford Reservoir, Mass. (Hemond and Eshleman, 1984). Results of Adirondack studies suggest that a large percentage of the nitrate released in the spring originates in the forest floor through mineralization of nitrogenous compounds, followed by nitrification (Peters and Driscoll, 1987). Biscuit Brook and the LTM streams had elevated nitrate concentrations during both the spring and fall high flows. Concentrations above $65 \mu \mathrm{eq} / \mathrm{L}$ were observed during fall storms on Rondout Creek and Biscuit Brook; peak values ranging from 40.5 to $92.8 \mu \mathrm{eq} / \mathrm{L}$ during snowmelt were observed in Biscuit Brook and the LTM streams, and these were equivalent to peak values observed in Adirondack streams during snowmelt in 1984 and 1985 (Peters and Driscoll, 1987). Nitrate concentrations in the regional-survey streams ranged from 61 to $100 \mu \mathrm{eq} / \mathrm{L}$ during the spring snowmelt of 1985 and 1986 (table 2). These high-flow or snowmelt-related increases in nitrate concentration, and the uniformity of average nitrate concentrations among the Biscuit Brook and the LTM streams as well as the regional-survey streams, suggest that nitrate sources are primarily atmospheric.
Increased concentrations of dissolved organic carbon (DOC) in Biscuit Brook and the LTM streams during high flows suggest a relation between stream acidity and DOC from soils (E.J. Krug, Illinois State Water Survey, written commun., 1986). Concentration of DOC in Biscuit Brook and the LTM streams ranged from 1 to $2 \mathrm{mg} / \mathrm{L}$ at base flow, and observed peak values ranged from $2.8 \mathrm{mg} / \mathrm{L}$ in Woodland Creek to $6.5 \mathrm{mg} / \mathrm{L}$ in the East Branch Neversink. An estimated organic-acid charge density of 4 to $5 \mathrm{meq} / \mathrm{mg}$ DOC in Adirondack lakes (Cronan and Aiken, 1985) would indicate that average peak DOC concentrations at Biscuit Brook could produce about $20 \mu \mathrm{eq} / \mathrm{L}$ of acidity; peak DOC concentrations observed in the other LTM streams could produce similar amounts. The DOC in Catskill streams is not necessarily all organic acid, however, and these weak acids may not be completely dissociated during periods of maximum $\mathrm{pH}$ depression.

\section{ACIDIFICATION OF CATSKILL STREAMS}

Determining the extent to which surface waters have become acidified in the Catskill region is made difficult by the lack of historical data on stream and lake chemistry. An analysis of the relative concentrations of constituents in the streams of this study can provide some indication of the current effect of acid deposition on stream acidity, however.

\section{Indications of Acidification}

Differences in alkalinity among Catskill streams and fluctuations in alkalinity with changing discharge have been shown to parallel local differences and temporal fluctuations in the base-cation concentrations, although the range of alkalinity values observed was less than the range of basecation concentrations (fig. 3, table 2). Decreased alkalinity during periods of increased discharge is caused at least partly by dilution, as evidenced by the decrease in base-cations concentrations and alkalinity with increasing flow. The dilution should affect base cations and alkalinity uniformly, but the difference in the range of values at high flows indicates that some form of acidification is occurring.

In a pristine carbonic-acid weathering system, stream alkalinity should be proportional to the production of base cations from weathering and therefore roughly equivalent to the sum of base- 
cation concentrations in the stream water (Likens and others, 1977; Henriksen, 1979). If the principal weathering minerals are carbonates, calcium and magnesium will be the predominant base-cations constituents of alkalinity, as observed in the Catskill streams. The alkalinity concentration in each of the Catskill streams was lower than the sum of $\mathrm{Ca}+\mathrm{Mg}$, however (fig. 3A), and this difference was similar among all streams observed. A relation between sulfate and alkalinity concentrations in Catskill streams is apparent in both the LTM and regionalsurvey data. A deviation from the equivalence line between alkalinity and calcium plus magnesium will result if acid deposition either (1) disproportionately decreases alkalinity with respect to $\mathrm{Ca}+\mathrm{Mg}$ by reaction of $\mathrm{HCO}_{3}$ with $\mathrm{H}$, or (2) increases the weathering of calcium and magnesium from rocks and soils. The deviation caused by either process would be approximately equal to the sulfate concentration (in microequivalents) above background levels if sulfuric acid were the cause. The alkalinity concentrations of the Catskill streams were 120 to $150 \mu \mathrm{eq} /$ L lower than the combined concentrations of calcium and magnesium (fig. 3A). When sulfate concentration is added to alkalinity and plotted against $\mathrm{Ca}+$ $\mathrm{Mg}$, a nearly 1:1 relation is evident (fig. 3B). Thus, sulfuric acid (and, to a lesser extent, nitric acid during high flows) strongly affects the relation between alkalinity and base-cation concentration in Catskill streams.
To achieve electroneutrality in aqueous solutions after alkalinity depletion, a deficit in base-cation concentrations relative to anion concentrations is compensated for by the release of protolytic cations - hydrogen and free aluminum-into solution (Driscoll and Newton, 1986). Concentrations of protolytic cations in several Adirondack lakes began to increase when the sum of acidic anions $\left(\mathrm{SO}_{4}+\mathrm{NO}_{3}\right)$ exceeded 90 percent of the basecation $(\mathrm{Ca}+\mathrm{Mg}+\mathrm{Na}+\mathrm{K})$ concentrations (Driscoll and Newton, 1985). A similar pattern was evident in the Catskill streams, where hydrogen and aluminum concentrations increased when the concentration of $\mathrm{SO}_{4}+\mathrm{NO}_{3}$ exceeded 80 percent of base-cation concentrations (fig. 4). Concentrations of protolytic cations above $60 \mu \mathrm{eq} / \mathrm{L}$ were observed primarily in the Roundout and Neversink basins.

Results of this study indicate a similarity among Catskill streams in their response to sulfuric and nitric acid deposition; the local differences in stream acidity are attributed to differences in the watersheds'buffering capacities. The regional-survey data indicate that, at base flow, 48 percent of the Catskill headwater streams are either insensitive to, or only slightly sensitive to, recent rates of acidic deposition (alkalinity $>200 \mu \mathrm{eq} / \mathrm{L}$ ), 45 percent are sensitive (alkalinity between 200 and $0 \mu \mathrm{eq} / \mathrm{L}$ ), and 7 percent are acidified (alkalinity $<0 \mu \mathrm{eq} / \mathrm{L}$ ).

Acidified headwater streams are more prevalent in the two southernmost basins--the Neversink and
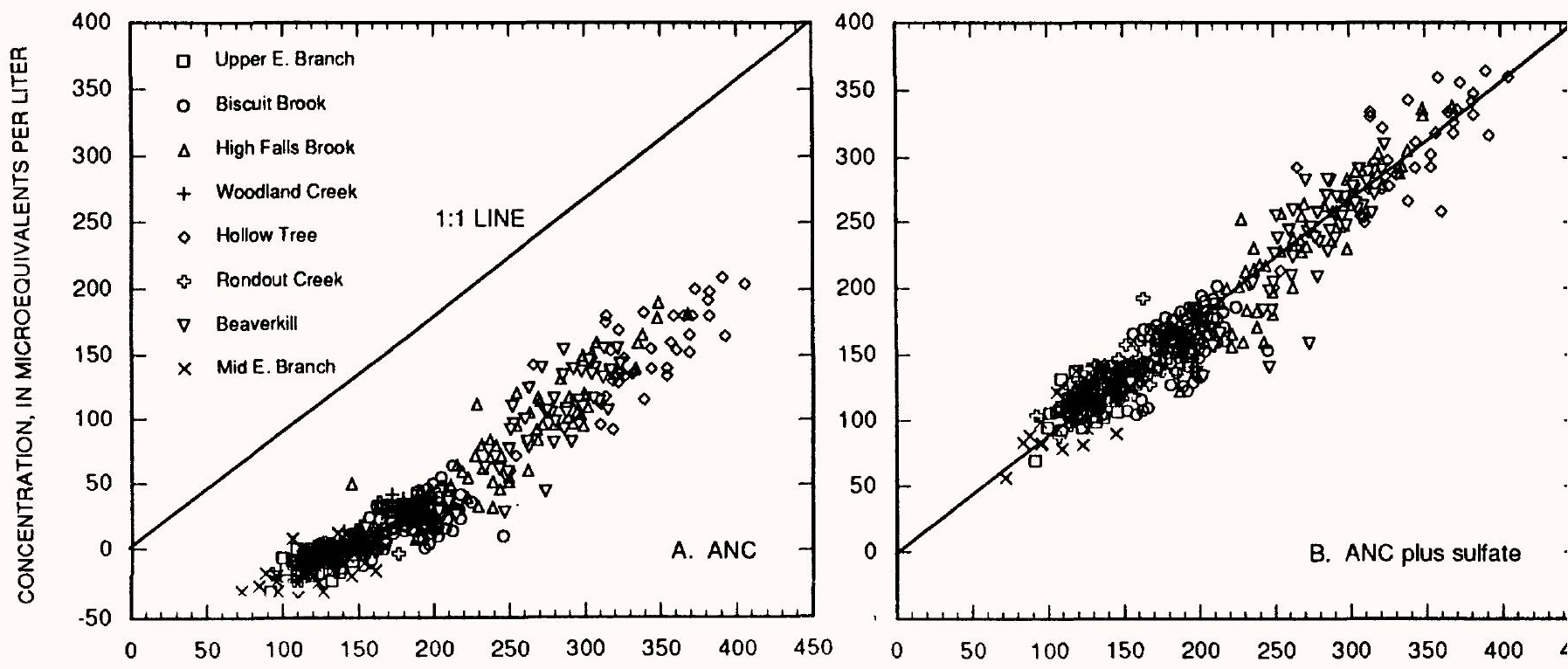

Figure 3. (A) Alkalinity, and (B) alkalinity plus sulfate in Biscuit Brook and Long-Term Monitoring streams, 1984-86. 
but at higher flows began to drop at a rate similar to that at Rondout Creek over its entire range of flows. The gradual decrease in alkalinity with increased discharge in each stream, however, indicates a threshold alkalinity value in these streams below which $\mathrm{pH}$ will begin to drop. An exception to this pattern was at Hollow Tree Brook and Woodland Creek, where $\mathrm{pH}$ remained relatively stable over the observed flow range. At $\mathrm{pH}$ values as high as 5.5 (fig. 6), aluminum concentrations in the primary streams exceeded $200 \mathrm{mg} / \mathrm{L}$, the level considered toxic to fish (Schofield, 1981),

Flow-duration curves, which illustrate the percentage of days per year that a given discharge is equaled or exceeded, can be used to estimate the frequency of selected discharges if a long-term discharge record is available (fig. 7). If the flowduration curves based on 35 years of record at the Neversink River at Claryville are assumed to represent flow duration per square kilometer at Biscuit Brook $15 \mathrm{~km}$ upstream, a pH below 5.0 and the associated high aluminum concentrations ( $>200$ $\mu \mathrm{eq} / \mathrm{L})$ can be expected to occur 4 days each year on the average (Murdoch, 1991). Although such projection from long-term records of large watersheds into headwater streams may have considerable uncertainty, the strong correlations observed between stream chemistry and flow at each stream in this study indicate that the frequency of episodic acidification in streams could be predicted from flowduration and flood-frequency analyses.

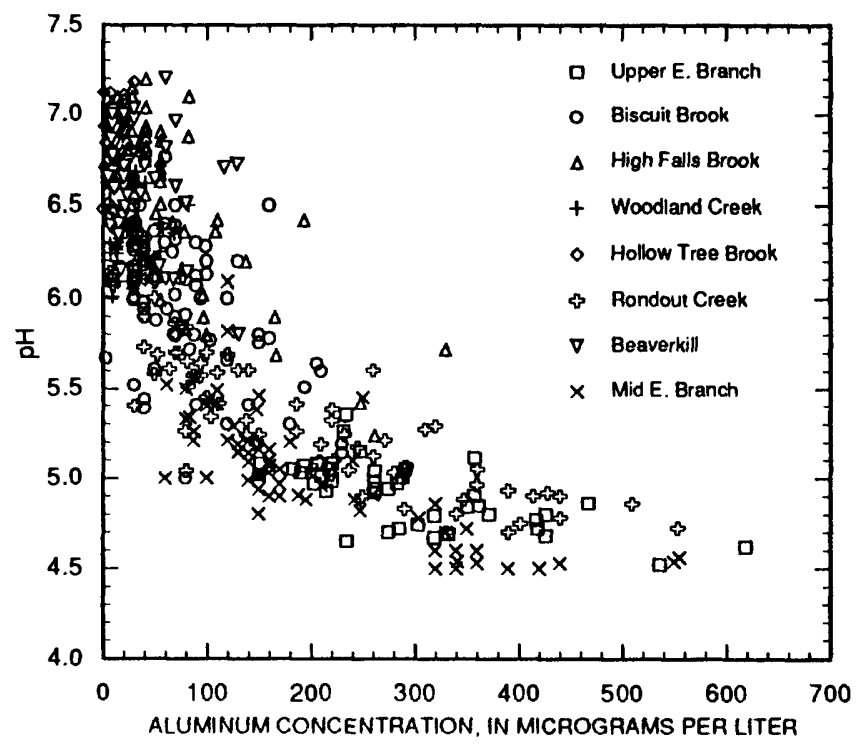

Figure 6. $\mathrm{pH}$ in relation to aluminum concentration at Biscuit Brook and the Long-Term Monitoring streams, 1984-86.
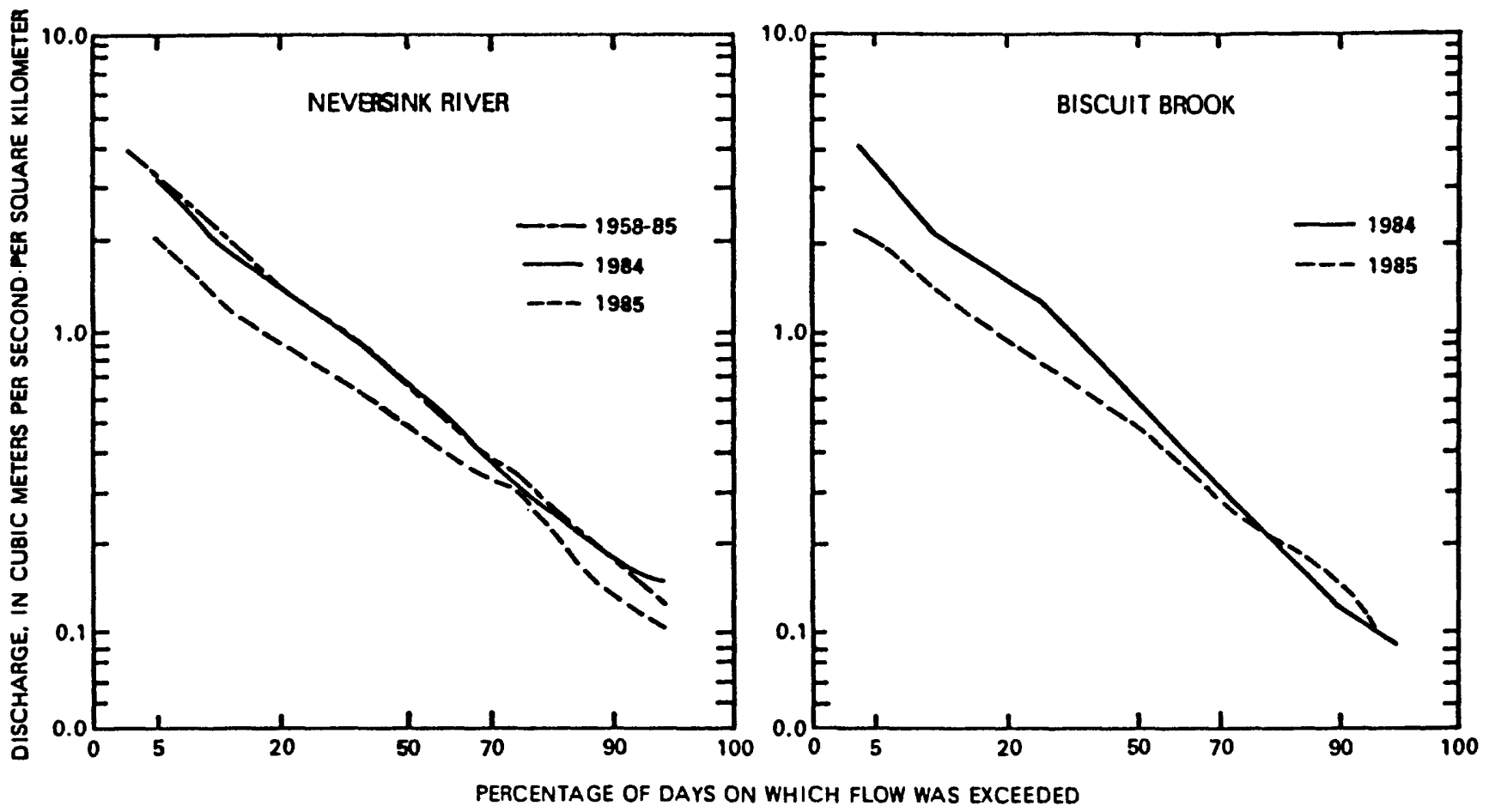

Figure 7. Flow-duration curves for the Neversink River near Claryville (1953-85) and Biscuit Brook (1984-85). (From Murdoch, 1991, fig. 2) 


\section{SUMMARY AND CONCLUSIONS}

Results of the first 3 years of precipitation monitoring at one stream, stream-discharge and water-quality monitoring at 8 streams and waterquality monitoring at 58 other streams in the Catskill Mountains, indicate that fluctuations in several chemical characteristics of these streams parallel those in other mountainous regions of the northeastern United States. Mean annual sulfate and nitrate concentrations in precipitation were similar to those in the Adirondack Mountains and at Hubbard Brook, N.H., although loadings may differ because the Catskills receive greater precipitation volume. Mean concentrations of sulfate and nitrate in streams were similar among the Catskill streams and also were similar to those at other sites in the Northeast. Local differences are probably related to the amount of development and the amount of agriculture and highway deicing within the respective watersheds. Differences in base-cation concentrations among streams partly reflect differences in land use among the major basins but are attributed mainly to local differences in thickness, permeability, and carbonate mineral content of upslope till deposits.

Alkalinity of the Catskill streams was directly related to base-cation concentration at all flows. Sulfate concentrations were similar among the streams over flows ranging through three orders of magnitude. Despite the significant correlation between base-cation concentrations and alkalinity, all streams had lower alkalinity than would be expected if all calcium and magnesium concentrations resulted from carbonate weathering. This difference ( 120 to $150 \mu \mathrm{eq} / \mathrm{L}$ ) is equivalent to the amount of sulfate observed in each stream. The uniformity of sulfate concentrations among Catskill streams indicates a common source, most probably sulfuric acid from atmospheric deposition.

Atmospheric deposition of nitrate exceeded the amount of nitrate in stream water, which indicates retention of nitrate in the watersheds. Stream nitrate concentrations increased during high flows in both the fall and spring. Acidification of stream water during high flows is attributed mainly to the increase in nitric acid but could also be caused partly by organic acids.

The increase in strong-acid anion concentrations over base cation concentrations during snowmelt and large storms was associated with elevated concentrations of hydrogen and aluminum in some streams. Of the 66 regional-survey streams studied, 48 percent are estimated to be insensitive to acid deposition, 45 percent are sensitive, and 7 percent are acidified.

Strong correlations between stream acidity and discharge were observed at each of the LTM streams, and the alkalinity of all of these streams except Hollow Tree Brook was near zero at discharges exceeding $0.6\left(\mathrm{~m}^{3} / \mathrm{s}\right) / \mathrm{km}^{2}$. These data indicate that the frequency of episodic acidification in streams could be predicted from flow-duration curves if longterm discharge records are available.

\section{REFERENCES}

Arnold, D.E., Light, R.W., and Paul, E.A.; 1985: Vulnerability of selected lakes and streams in the Middle Atlantic region to acidification--a regional survey: U.S. Fish and Wildlife Service, Biological Report FWS/OBS-80/40.19, 133 p.

Ceraso, Jane, Epstein, C.B., Clarke, S.L., and Oppenheimer, Michael, 1986, New York City's water supply--acid deposition, inorganic pollution, and the Catskill reservoirs: New York, Environmental Defense Fund, $138 \mathrm{p}$.

Cronan, C.S., and Aiken, G.R., 1985, Chemistry and transport of soluble humic substances in forested watersheds of the Adirondack Park, New York: Geochemica et Cosmochemica Acta, v. 49, p. 1697 1705.

Drever, J.I., and D.R. Hurcomb, 1986, Neutralization of atmospheric acidity by chemical weathering in and alpine drainage basin in the North Cascade Mountains: Geology, v. 14, p. 221-224.

Driscoll, C.T., and Newton, R.M., 1986, Chemical characteristics of Adirondack Lakes: Environmental Science and Technology, v. 19, no. 11, p. 1018-1024.

Ethridge, F.G., 1977, Petrology, transport, and environment in isochronous Upper Devonian sandstone and siltstone units, New York: Journal of Sedimentary Petrology, v. 47 , no. 1, p. $63-65$.

Fishman, M.J., and Friedman. L.C., 1985, Methods for determination of inorganic substances in water and fluvial sediments: U.S. Geological Survey Techniques of Water Resource Investigations, Book 5, Chapter A1, $709 \mathrm{p}$.

Haines, T.A., and Akielaszek, J., 1983, A regional survey of the chemistry of headwater lakes and streams in New England-vulnerability to acidification: U.S. Fish and Wildlife Service Report FWS/OBS-80/40.15, 141 p. 
Hemond, H.F., and Eshleman, K.N., 1984, Neutralization of acid deposition by nitrate retention at Bickford watershed, Massachusetts: Water Resources Research, v. 20 , no. 11 , p. 1718-1724.

Henriksen, A., 1979, A simple approach for identifying and measuring acidification of fresh water: Nature, v. 28, p. 542-545.

Katz, B.G., Bricker, O.P., and Kennedy, M.M., 1985, Geochemical mass-balance relationships for selected ions in precipitation and stream water, Catoctin Mountains, Maryland: American Journal of Science, v. 285, p. 931-962.

Krug, E.C., and Frink, C.R., 1983, Acid rain on acid soil--a new perspective: Science, v. 221, p. 520-525.

Johnson, N.M., Likens, G.E., Bormann, F.H., Fisher, D.W., and Pierce, R.S., 1969, A working model for the variation in streamwater chemistry at the Hubbard Brook Experimental Forest, New Hampshire: Water Resources Research, v. 5, no. 6, p. 1353-1363.

Likens, G.E., ed., 1985, An ecosystem approach to aquatic ecology-Mirror Lake and its environments: New York, Springer-Verlag, $516 \mathrm{p}$.

Likens, G.E., Bormann, F.H., Pierce, R.S., Eaton, I.S., and Johnson, N.M., 1977, Biogeochemistry of a forested ecosystem: New York, Springer-Verlag, 146 p.

Lynch, D.D., and Dise, N.B., 1985, Sensitivity of stream basins in Shenandoah National Park to acid deposition: U.S. Geological Survey Water- Resources Investigations Report 85-115, 61 p.

Murdoch, P.S., 1991, Chemical budgets and streamchemistry dynamics at Biscuit Brook in the Catskill Mountains, New York, 1984-85: U.S. Geological Survey Water-Resources Investigations Report 88-4035, $66 \mathrm{p}$.
National Oceanic and Atmospheric Administration, 197485, Climatological data annual summary: Asheville, N.C. National Climatic Center, v. 83-94.

National Research Council, 1983, Acid deposition-atmospheric processes in eastern North America: Washington, D.C., National Academy Press, 378 p.

Parker, G.G., Hely, A.G., Keighton, W.B., Olmstead, F.H., and others, 1964, Water resources of the Delaware River basin: U.S. Geological Survey Professional Paper 381. $200 \mathrm{p}$.

Peters, N.E., and Driscoll, C.T., 1987, Sources of acidity during snowmelt at a forested site in the West Central Adirondack Mountains, New York, in Swanson, R.H., Bernier, T.Y., and Woodard, P.D., (eds.), Forest Hydrology and Watershed Management: Inter-national Association of Hydrologic Sciences, v. 167, p. 99-108.

Peters, N.E., and Murdoch, P.S., 1985, Hydrogeologic comparison of an acidic-lake basin and a neutral-lake basin in the west-central Adirondack Mountains, New York: Water, Air, and Soil Pollution, v. 26, p. 387-402.

Rich, J.L., 1934, Glacial geology of the Catskills: New York State Museum Bulletin 299, 180 p.

Rosenquist, I.T., 1978, Alternative sources of acidification of river water in Norway: Science of the Total Environment, v. 10, p. 39-49.

Schofield, C.L., 1981, Acid precipitation-Effects on fish: Ambio, v. 5, no. 5-6, p. 228-238.

Stoddard, J.L., and Murdoch, P.S., 1991, Catskill Mountains, in Charles, D.F. (ed.), Acidic Deposition and Aquatic Ecosystems-Regional Case Studies: New York, Springer Verlag, $600 \mathrm{p}$.

Way, J.H., 1972, A more detailed discussion of the depositional environmental analysis--middle and upper Devonian sedimentary rocks, Catskill Mountain area, New York: Troy, N.Y., Rensselaer Polytechnic Institute, Ph.D. dissertation, $145 \mathrm{p}$. 